\title{
Nutrient Management in kharif Rice (Oryza sativa L.) through Inorganic and Organic Sources for Enhancing Productivity and Profitability in konkan Region of Maharashtra
}

\author{
V. V. Warankar, Y. S. Chavan*, A. N. Jadhav, M. E. Bahiram, A. M. Gaikwad, \\ V. G. Chavan, VA. Rajemahadik, VV. Sagavekar and S. A. Chavan
}

Department of Agronomy, Dr.B.S.Konkan Krishi Vidyapeeth, Dapoli Dist.- Ratnagiri (MS.), India

*Corresponding author

\section{A B S T R A C T}

\begin{tabular}{|l|}
\hline Ke y w o r d s \\
$\begin{array}{l}\text { Nutrient sources, } \\
\text { Rice, Inorganic } \\
\text { organic, } \\
\text { Productivity and } \\
\text { Profitability }\end{array}$ \\
\hline Article Info \\
\hline $\begin{array}{l}\text { Accepted: } \\
\text { 04 November } 2020 \\
\text { Available Online: } \\
\text { 10 December } 2020\end{array}$ \\
\hline
\end{tabular}

A field experiment was conducted during the kharif, 2018 at Agronomy Farm, College of Agriculture, Dapoli, Dist. Ratnagiri (M.S.), to study the "Nutrient management in kharif rice (Oryza sativa L.) through inorganic and organic sources for enhancing productivity and profitability in konkan region of Maharashtra." The experiment was laid out in split plot design which comprising of 25 treatment combinations replicated thrice. Main plot treatment consisted of five levels of nitrogen through urea $\left(\mathrm{N}_{1}-100\right.$ per cent $\mathrm{RDN}, \mathrm{N}_{2}-75$ per cent RDN, $\mathrm{N}_{3}-50$ per cent RDN, $\mathrm{N}_{4}-25$ per cent RDN and $\mathrm{N}_{5}$-No fertilizer (control) and sub-plot treatment comprised of five levels of nitrogen through FYM ( $\mathrm{M}_{1}-100$ per cent RDN, $\mathrm{M}_{2}-75$ per cent RDN, $\mathrm{M}_{3}-50$ per cent RDN, $\mathrm{M}_{4}-25$ per cent RDN and $\mathrm{M}_{5}$-No FYM (control).The experimental plot was sandy clay loam in texture, moderately acidic in reaction with very high in organic carbon content. Soil was low in available nitrogen, low in available phosphorus and moderately high in available potassium. The experimental results revealed that application of 100 per cent RDN through urea recorded significantly higher growth parameters and yield attributes resulting into significantly more grain and straw $\left(\mathrm{q} \mathrm{ha}^{-1}\right)$ than remaining levels of nitrogen. The highest gross returns of Rs.1,25,685 ha ${ }^{-1}$, net returns of Rs. 6,974 ha ${ }^{-1}$ and benefit to cost ratio of 1.06 were obtained due to application of 100 per cent RDN through urea. Among the levels of nitrogen through FYM, 100 per cent RDN $\left(M_{1}\right)$ recorded significantly higher value of growth parameters and yield attributes which resulting into significantly more grain and straw yields (q $\mathrm{ha}^{-1}$ ) than remaining levels of nitrogen under the investigation. Significantly highest net monitory returns of Rs. $22,650 \mathrm{ha}^{-1}$ and B:C ratio of 1.30 registered under the treatment $\left(\mathrm{N}_{5}\right)$ No FYM (control) than other higher levels of FYM during year of experimentation. Among the different treatment combinations, the highest net returns and $\mathrm{B}: \mathrm{C}$ ratio of Rs. 32, $749 \mathrm{ha}^{-1}$ and 1.41 , respectively were obtained under treatment combination of $\left(\mathrm{N}_{1} \mathrm{M}_{5}\right)$ i.e. 100 per cent RDN through urea with no FYM.

\section{Introduction}

Rice (Oryza sativa L.) is the world's second most important cereal crop and staple food of large number of people. India exports around 10.3 million metric tonnes of rice. Total global consumption of milled rice amounted to approximately 477.77 million metric 
tonnes in 2016-2017. China consumed around 146 million metric tonnes of milled rice per year and was the world's leading rice consumer in that year. In comparison, the U.S. consumed some 3.85 million metric tonnes (Anonymous-2017). In Maharashtra area under rice crop in 2016-17 was 1.63 million hectares with production of 3.35 million tonnes. An average productivity of the state is $2059 \mathrm{~kg} \mathrm{ha}^{-1}$. The average productivity of the Maharashtra state is low as compared to other rice growing states viz. West Bengal, Uttar Pradesh, Punjab, Odisha, Tamil Nadu, Haryana, Andhra Pradesh etc. (Anonymous2017). Konkan region occupies an area of about 3.69 lakh hectares under rice with production of about 10.83 lakh tonnes and productivity around $2930 \mathrm{~kg} \mathrm{ha}^{-1}$. The area, production and average productivity of the Konkan region was more as compared to Western Maharashtra, Marathwada and Vidarbha (Anonymous-2016).

The effect of continuous and indiscriminate use of inorganic fertilizers has resulted in contamination of ground water and decrease in the productivity of soil, which in turn affects the rice production in long term. Use of organic manures may help to improve the soil health, however, the available quantity is insufficient therefore the farmers cannot achieved optimal growth and production. Hence use of organic manures in combination with inorganic fertilizers in judicious manner is the need of current era to obtained optimum yield and maintain soil health.

The integrated nutrient management approach aims at efficient and judicious use of all the major sources of plant nutrients in an integrated manner, so as to get maximum economic yield without any deleterious effect on physico-chemical and biological properties of the soil. Thus, the basic concept underlying the principles of integrated nutrient management is the maintenance and possible improvement in soil fertility for sustained crop productivity on long term basis. The major components of integrated nutrient supply system are fertilizer, FYM, vermicompost, green manure, crop residue/recyclable wastes and bio-fertilizers. These components possess great diversity in terms of chemical and physical properties, nutrient release efficiencies, positional availability, crop specificity and farmers acceptability.

Biofertilizers are a substance which contains living microorganisms which, when applied to seed, plant surfaces, or soil, colonizes the rhizosphere or the interior of the plant and promotes growth by increasing the supply or availability of the nutrients to the host plant (Vessey, 2003). Bio-fertilizers add nutrients through the natural processes of nitrogen fixation, solubilizing phosphorus and stimulating plant growth through the synthesis of growth-promoting substance. Bio fertilizers, an alternate low cost resource have gained prime importance in recent decades and play a vital role in maintaining long term soil fertility and sustainability. They are cost effective, eco-friendly and renewable sources of plant nutrients to supplement chemical fertilizers. Nitrogen fixing and P-solubilizing inoculants are important biofertilizers used in rice.

Therefore, the combination of different components to ensure optimum nutrient supply to a production system may depend on land use, ecological, social and economic condition. Indian agriculture had been traditionally dependent on organic manure sources and the inclusion of FYM regulates nutrient uptake, crop yields and physical status of soil and thus has a synergistic effect. Nutrient management is an important aspect in rice to be given pivotal importance so as to attain sustainability of grain and straw production. The integration of fertilizers 
along with organic manures may affect biometric characteristics and ultimately on grain and straw yields of rice.

Nutrient management technology is oriented towards better utilization of organic sources that may be available cheaply, along with improving the formulation, time of application and placement of chemical fertilizers so that the nutrient uptake by plants is maximized. Keeping these points in the view, the proposed research entitled "Nutrient management in kharif rice (Oryza sativa L.) through inorganic and organic sources for enhancing productivity and profitability" is planned at Agronomy Farm, College of Agriculture, Dapoli during kharif season of 2018.

\section{Materials and Methods}

A field experiment was conducted during the kharif, 2018 at Agronomy Farm, plot No. 20, College of Agriculture, Dapoli, Dist. Ratnagiri (M.S.) to study the "Nutrient management in kharif rice (Oryza sativa L.) through inorganic and organic sources for enhancing productivity and profitability" on lateritic soil having low to moderate soil fertility status. The topography of the experimental plot was uniform and levelled. The soil of experimental site was well drained. The composite soil sample from 0 to $30 \mathrm{~cm}$ layer was taken with the help of a screw auger before starting of a field experiment. Agronomy farm, college of Agriculture, Dapoli, Dist. Ratnagiri is situated in a tropical region at 170 4' North latitude and 730 1' East longitude having an elevation of 250 meters above mean sea level. The experiment was laid out in split plot design which comprising of 25 treatment combinations replicated thrice. Main plot treatment consisted of five levels of nitrogen through urea $\left(\mathrm{N}_{1}-100\right.$ per cent $\mathrm{RDN}, \mathrm{N}_{2}-75$ per cent $\mathrm{RDN}, \mathrm{N}_{3}-50$ per cent $\mathrm{RDN}, \mathrm{N}_{4}-25$ per cent $\mathrm{RDN}$ and $\mathrm{N}_{5}-\mathrm{No}$ fertilizer (control) and sub-plot treatment comprised of five levels of nitrogen through FYM $\left(\mathrm{M}_{1}-100\right.$ per cent RDN, $\mathrm{M}_{2}-75$ per cent $\mathrm{RDN}, \mathrm{M}_{3}-50$ per cent $\mathrm{RDN}, \mathrm{M}_{4}-25$ per cent $\mathrm{RDN}$ and $\mathrm{M}_{5}-\mathrm{No}$ FYM (control).

During the course of investigation, growth observations of rice were recorded periodically from 30 DAT till the harvest at an interval of 30 days. The yield contributing characters and yield were recorded at harvest to evaluate the treatment effects. The uptake of major nutrients by the rice was analyzed and interpreted. Similarly, economics of different treatments was worked out along with the interaction. The experimental plot was sandy clay loam in texture, moderately acidic in reaction with very high in organic carbon content. Soil was low in available nitrogen, low in available phosphorus and moderately high in available potassium. In case of nutrient management factor, at the time of transplanting 50 per cent nitrogen from each level of 100 per cent, 75 per cent, 50 per cent, and 25 per cent of the recommended $\mathrm{N} \mathrm{ha}^{-1}$ was applied as per the treatment with full dose of $\mathrm{P}_{2} \mathrm{O}_{5}$ and $\mathrm{K}_{2} \mathrm{O}$ as a basal dose. The remaining 50 percent nitrogen from the four levels was applied in two equal split i.e. at maximum tillering stage (30 DAT)and panicle initiation stage (60 DAT) as per the treatments.

\section{Results and Discussion}

\section{Effect of levels of nitrogen through urea}

The data presented in Table 1 revealed that, the mean plant height of rice was significantly influenced due to the application of nitrogen through urea throughout the growth period of the crop. Among the different levels of nitrogen through urea the treatment $\mathrm{N}_{1}(100$ per cent RDN) produced significantly taller plant at harvest over the treatment which 
supplied 50 per cent RDN, 25 per cent RDN and control and it was at par with treatment $\mathrm{N}_{2}$ (75 per cent RDN). The mean number of tillers hill ${ }^{-1}$ of rice was influenced significantly due to the different levels of nitrogen through urea during the entire growth period of the crop. Among the different levels of nitrogen, the treatment $\mathrm{N}_{1}-100$ per cent $\mathrm{RDN}$ produced significantly higher number of tillers hill ${ }^{-1}$ at harvest over $\left(\mathrm{N}_{3}\right) 50$ per cent $\mathrm{RDN},\left(\mathrm{N}_{4}\right) 25$ per cent $\mathrm{RDN}$ and $\left(\mathrm{N}_{5}\right)$ control treatment. However, it was at par $\left(\mathrm{N}_{2}\right)$ i.e. 75 per cent $\mathrm{RDN}$ at all the growth stages of rice.The different levels of fertilizer significantly influenced the mean number of functional leaves hill $^{-1}$ of rice throughout the growth stages. Significantly more number of functional leaves hill $^{-1}$ was recorded with application of 100 per cent $\mathrm{RDN}\left(\mathrm{N}_{1}\right)$ than 25 per cent RDN $\left(\mathrm{N}_{4}\right)$ and control $\left(\mathrm{N}_{5}\right)$ and it was at par with 75 per cent RDN $\left(\mathrm{N}_{2}\right)$ and 50 per cent $\mathrm{RDN}\left(\mathrm{N}_{3}\right)$ at all the growth stages of rice.

Further, it was found that, application of 100 per cent RDN $\left(\mathrm{N}_{1}\right)$ through urea recorded significantly higher dry matter accumulation hill $^{-1}$ over 50 per cent RDN $\left(\mathrm{N}_{3}\right), 25$ per cent $\operatorname{RDN}\left(\mathrm{N}_{4}\right)$ and $\left(\mathrm{N}_{5}\right)$ control treatments and was at par with 75 per cent $\operatorname{RDN}\left(\mathrm{N}_{2}\right)$ at 60 DAT and at harvest stage. However, at 90 DAT it was at par with 75 per cent RDN and 50 per cent RDN and significantly superior over rest of the treatments. However, application of 100 per cent RDN through urea $\left(\mathrm{N}_{1}\right)$ recorded significantly more number of effective tillers hill ${ }^{-1}$ over rest of the levels of nitrogen supplied through urea.It is evident from the data presented that a remarkable influence of various levels of nitrogen through urea on the growth characters of rice crop was observed during the entire growth stages of the crop. Moreover, the nitrogen levels showed significant variation in the growth and development parameters of rice viz. plant height $(\mathrm{cm})$, number of tillers hill ${ }^{-1}$, number of functional leaves hill ${ }^{-1}$, dry matter accumulation hill $^{-1}$ and number of effective tillers hill $^{-1}$ due to the different levels of nitrogen through urea during the experimentation. These findings were supported by Chaturvedi (2005), he stated that, the increase in plant height in response to application of $\mathrm{N}$ fertilizers is probably due to enhanced availability of nitrogen which enhanced more leaf area resulting in higher photo assimilates and thereby resulted in more dry matter accumulation. The results are in agreement with the findings reported by Kumar, et al., (2017) and Marskole et al., (2017).

Data regarding yield contributing characters viz., length of panicle $(\mathrm{cm})$, weight of panicle $(\mathrm{g})$, number of filled grains panicle ${ }^{-1}$, number of unfilled grains panicle ${ }^{-1}$ and test weight ( $\mathrm{g}$ ) as affected by the various treatments are presented in Table 2.

Application of 100 per cent $\operatorname{RDN}\left(\mathrm{N}_{1}\right)$ significantly increased the length of panicle over the 50 per cent RDN, 25 per cent RDN and control treatment and it was at par with 75 per cent $\mathrm{RDN}\left(\mathrm{N}_{2}\right)$. Weight of panicle increased with increase in the level of nitrogen and it was higher in treatment $\left(\mathrm{N}_{1}\right) 100$ per cent RDN (5.95) than $\left(\mathrm{N}_{4}\right) 25$ per cent RDN and $\left(\mathrm{N}_{5}\right)$ control. However, it was at par with 75 per cent RDN $\left(\mathrm{N}_{2}\right)$ and 50 per cent $\mathrm{RDN}\left(\mathrm{N}_{3}\right)$ through urea. Application of fertilizers significantly influenced the number of filled grains panicle ${ }^{-1}$. The treatment 100 per cent $\mathrm{RDN}$ through urea $\left(\mathrm{N}_{1}\right)$ produced significantly higher number of filled grains panicle ${ }^{-1}$ over the treatments $\left(\mathrm{N}_{4}\right) 25$ per cent RDN and $\left(\mathrm{N}_{5}\right)$ control. Further, 100 per cent RDN $\left(\mathrm{N}_{1}\right)$ was at par with 75 per cent RDN $\left(\mathrm{N}_{2}\right)$ and 50 per cent RDN $\left(\mathrm{N}_{3}\right)$. The number of unfilled grains panicle ${ }^{-1}$ was significantly influenced due to the different levels of nitrogen through urea. The number of unfilled grains panicle ${ }^{-1}$ was significantly more in treatment $\left(\mathrm{N}_{1}\right) 100$ per cent $\mathrm{RDN}$ (52.41) over 
rest of the levels of nitrogen under study except $\left(\mathrm{N}_{2}\right) 75$ per cent RDN which was at par with $\left(\mathrm{N}_{1}\right)$. The lower number of unfilled grains panicle ${ }^{-1}$ (37.32) was found in control treatment. The treatment $\left(\mathrm{N}_{1}\right) 100$ per cent RDN recorded significantly higher thousand grain weight $(17.39 \mathrm{~g})$ over $\left(\mathrm{N}_{3}\right) 50$ per cent $\mathrm{RDN},\left(\mathrm{N}_{4}\right) 25$ per cent $\mathrm{RDN}$ and $\left(\mathrm{N}_{5}\right)$ control and $\left(\mathrm{N}_{2}\right) 75$ per cent RDN which was at par with $\left(\mathrm{N}_{1}\right)$. Among the different levels lowest value of test weight found in control treatment of $(16.17 \mathrm{~g})$.

The different levels of fertilizer significantly influenced the grain yield $\left(\mathrm{q} \mathrm{ha} \mathrm{h}^{-1}\right)$ of rice. These treatments can be arranged in the following order of significance in respect of the grain yield viz. 100 per cent $\operatorname{RDN}\left(\mathrm{N}_{1}\right)>$ 75 per cent $\operatorname{RDN}\left(\mathrm{N}_{2}\right)>50$ per cent $\mathrm{RDN}$ $\left(\mathrm{N}_{3}\right)>25$ per cent $\mathrm{RDN}\left(\mathrm{N}_{4}\right)>\left(\mathrm{N}_{5}\right)$ control. Higher growth and yield attributing characters of rice obtained due to the application of 100 per cent RDN through urea $\left(\mathrm{N}_{1}\right)$ resulted into production of significantly higher grain, straw and total biological yields as compared to the other levels. The increment in grain and straw yields in this study at higher nitrogen levels might be due efficient absorption of nitrogen and other elements which raise the production and translocation of the dry matter from source to sink. The results are in the conformity with the work done by Babu, et al., (2017) \& Kumar, et al., (2017).

The different levels of fertilizer significantly influenced the straw yield $\left(\mathrm{q} \mathrm{ha} \mathrm{h}^{-1}\right)$ of rice. Application of 100 per cent RDN through urea $\left(\mathrm{N}_{1}\right)$ recorded significantly higher straw yield of $\left(76.73 \mathrm{q} \mathrm{ha}^{-1}\right)$ than the remaining levels of nitrogen i.e. 75 per cent $\operatorname{RDN}\left(\mathrm{N}_{2}\right)$, 50 per cent $\mathrm{RDN}\left(\mathrm{N}_{3}\right), 25$ per cent $\mathrm{RDN}\left(\mathrm{N}_{4}\right)$ and $\left(\mathrm{N}_{5}\right)$ control in that descending order of significance.Increased gross returns, net returns and benefit to cost ratio under higher nitrogen levels was mainly due to increase in the grain and straw yield. Similar findings were also reported by Kafle (2014), Dangi (2016) and Babu, et al., (2017). Yadav et al., (2008) reported that, the output capacity in terms of Rs. ha ${ }^{-1}$ was more under $\mathrm{M}_{3}$ (RDF 80:50:50 kg NPK ha-1). The experimental results revealed that application of 100 per cent RDN through urea recorded significantly higher growth parameters and yield attributes resulting into significantly more grain and straw (q ha-1) than remaining levels of nitrogen. The highest gross returns of Rs. $1,25,685$ ha-1, net returns of Rs. 6,974 ha-1 and benefit to cost ratio of 1.06 were obtained due to application of 100 per cent RDN through urea.

\section{Effect of levels of nitrogen through FYM}

The mean plant height of rice at the different stages of crop growth was significantly influenced due to the levels of nitrogen applied through FYM. The data presented in Table 1 showed that among the different levels of nitrogen the treatment $\mathrm{M}_{1}-100$ per cent RDN recorded significantly higher plant height over the other levels of nitrogen at 30 DAT. However, at 90 DAT and at harvest the treatmentM 1 (100 per cent $\mathrm{RDN})$ recorded significantly taller plant height than treatment $\mathrm{M}_{4}-25$ per cent $\mathrm{RDN}$ and $\mathrm{M}_{5}-\mathrm{No}$ FYM (Control) and it was at par with treatment $\mathrm{M}_{2}$ (75 per cent $\mathrm{RDN}$ ) and $\mathrm{M}_{3}$ (50 per cent RDN). Further, it was noticed that at 60 DAT the treatment $\mathrm{M}_{1}-100$ per cent $\mathrm{RDN}$ recorded significantly taller plant height over rest of the levels of nitrogen through FYM under study except the treatment $\mathrm{M}_{2}-75$ per cent RDN, which was at par with $\mathrm{M}_{1}-100$ per cent RDN.

The mean number of tillers hill $^{-1}$ of rice was significantly influenced due to the levels of nitrogen through FYM. The data indicated that treatment $\mathrm{M}_{1}-100$ per cent RDN produced significantly higher number of tillers hill $^{-1}$ at harvest than control treatment and it was at par with 75 per cent RDN, 50 
per cent RDN and 25 per cent RDN. However, at 90 DAT significantly higher number of tillers hill ${ }^{-1}$ was produced in the treatment with 100 per cent RDN over the remaining levels of nitrogen.

The data indicated application of 100 per cent RDN $\left(\mathrm{M}_{1}\right)$ recorded significantly more number of functional leaves hill ${ }^{-1}$ over application of 25 per cent $\operatorname{RDN}\left(\mathrm{M}_{4}\right)$ and control $\left(\mathrm{M}_{5}\right)$ at all the stages of crop growth and it was at par with 75 per cent $\operatorname{RDN}\left(\mathrm{M}_{2}\right)$ and 50 per cent RDN $\left(\mathrm{M}_{3}\right)$ except at harvest where it has recorded more number of functional leaves hill ${ }^{-1}$ over 50 per cent RDN, 25 per cent RDN and control treatment and it was at par with 75 per cent RDN.Dry matter accumulation (g) hill $^{-1}$ was significantly influenced due to different levels of nitrogen through FYM at harvest.

However, significantly higher dry matter accumulation (g) hill ${ }^{-1}$ was recorded by the crop in treatment $\left(\mathrm{M}_{1}\right) 100$ per cent RDN through FYM than 25 per cent RDN $\left(\mathrm{M}_{4}\right)$ and control $\left(\mathrm{M}_{5}\right)$ and it was at par with 75 per cent RDN and 50 per cent RDN at 60 DAT and at harvest. However, at 90 DAT, treatment 100 per cent RDN through FYM $\left(\mathrm{M}_{1}\right)$ was at par with 75 per cent RDN through FYM $\left(\mathrm{M}_{2}\right)$ and significantly superior over rest of the treatments. The treatment $\left(\mathrm{M}_{1}\right)$ i.e. 100 per cent RDN through FYM produced significantly taller plants in all the growth stages as compared to other levels. On the other hand, lower plant height was found in control treatment $\left(\mathrm{M}_{5}\right)$ at all growth stages. Srivastava et al., (2013) reported that, the plant height increases with increase in the dose of nitrogen through FYM. This could be due to sufficient amount of $\mathrm{N}$ supplied through FYM having narrow $\mathrm{C}: \mathrm{N}$ ratio that might have helped in mineralization and release of nutrients in adequate amount. This has contributed in promoting the growth as nitrogen is very important for plant growth.
Similar findings were noted by Shah, et al., (2001), Gopakkali (2010) and Kafle (2014).

The data in Table no. 1 summarized that significantly higher number of effective tillers hill $^{-1}$ was recorded in treatment which supplied 100 per cent RDN (M $\left.\mathbf{M}_{1}\right)$ through FYM than control treatment $\left(\mathrm{M}_{5}\right)$ and it was at par with 75 per cent RDN, 50 per cent RDN and 25 per cent RDN through FYM. Among the various levels of nitrogen applied through FYM, 100 per cent RDN $\left(\mathrm{M}_{1}\right)$ recorded significantly longer length of panicle than 25 per cent RDN and control treatment. However, the treatment 100 per cent RDN $\left(\mathrm{M}_{1}\right)$ was at par with 75 per cent $\mathrm{RDN}\left(\mathrm{M}_{2}\right)$ and 50 per cent $\mathrm{RDN}\left(\mathrm{M}_{3}\right)$.

It is seen from the data presented in Table 2 that, the treatment 100 per cent RDN i.e. $\left(M_{1}\right)$ recorded significantly higher weight of panicle over 25 per cent RDN and control and it was at par with 75 per cent $\mathrm{RDN}\left(\mathrm{M}_{2}\right)$ and 50 per cent RDN $\left(\mathrm{M}_{3}\right)$ through FYM. Application of 100 per cent $\operatorname{RDN}\left(\mathrm{M}_{1}\right)$ through FYM produced significantly higher number of filled grains panicle ${ }^{-1}$ than $\left(M_{4}\right) 25$ per cent $\mathrm{RDN}$ and $\left(\mathrm{M}_{5}\right)$ control treatment. However, 100 per cent RDN $\left(\mathrm{M}_{1}\right)$ was at par with 75 per cent RDN $\left(\mathrm{M}_{2}\right)$ and 50 per cent $\mathrm{RDN}\left(\mathrm{M}_{3}\right)$.

Application of FYM to rice significantly affected the number of unfilled grains panicle $^{-1}$. The Number of unfilled grains panicle $^{-1}$ in treatment $\left(M_{1}\right) 100$ per cent RDN (47.61) was significantly higher over $\left(\mathrm{M}_{5}\right)$ control (41.00). Further, treatment $\left(\mathrm{M}_{1}\right)$ was at par with $\left(\mathrm{M}_{2}\right) 75$ per cent $\mathrm{RDN},\left(\mathrm{M}_{3}\right) 50$ per cent RDN and $\left(\mathrm{M}_{4}\right) 25$ per cent RD. Among the different levels of nitrogen through FYM, 100 per cent RDN $\left(M_{1}\right)$ recorded higher thousand grain weight (17.03 g) than $\left(\mathrm{M}_{3}\right) 50$ per cent $\mathrm{RDN},\left(\mathrm{M}_{4}\right) 25$ per cent RDN and $\left(\mathrm{M}_{5}\right)$ control. However, $\left(\mathrm{M}_{2}\right)$ 75 per cent RDN was at par with $\left(\mathrm{M}_{1}\right)$. 
Table.1 Mean plant height $(\mathrm{cm})$, number of tiller hill-1, number of functional leaves hill-1, dry matter accumulation hill-1 and number of effective tillers hill ${ }^{-1}$ at harvest

\begin{tabular}{|c|c|c|c|c|c|}
\hline Treatment & $\begin{array}{l}\text { Plant height } \\
(\mathrm{cm})\end{array}$ & $\begin{array}{l}\text { Number of } \\
\text { tillers hill }\end{array}$ & $\begin{array}{l}\text { Number of functional } \\
\text { leaves } \text { hill l}^{-1}\end{array}$ & $\begin{array}{c}\text { Dry matter } \\
\text { accumulation hill } \\
\text { (g) }\end{array}$ & $\begin{array}{c}\text { Number of } \\
\text { effective tillers hill } \\
1\end{array}$ \\
\hline \multicolumn{6}{|c|}{ Main plot treatment - Level of nitrogen through urea } \\
\hline$N_{1}-100 \%$ RDN & 75.30 & 5.75 & 4.17 & 67.08 & 5.41 \\
\hline $\mathrm{N}_{2}-75 \% \mathrm{RDN}$ & 74.20 & 5.31 & 3.68 & 64.48 & 5.03 \\
\hline $\mathrm{N}_{3}-50 \% \mathrm{RDN}$ & 73.02 & 4.99 & 3.36 & 60.89 & 4.59 \\
\hline $\mathrm{N}_{4}-25 \%$ RDN & 71.54 & 4.60 & 2.76 & 58.35 & 4.33 \\
\hline $\begin{array}{l}\mathrm{N}_{5}-\mathrm{No} \text { fertilizer } \\
\text { (Control) }\end{array}$ & 67.19 & 4.03 & 2.19 & 54.60 & 3.88 \\
\hline $\mathrm{SE} \pm$ & 0.63 & 0.16 & 0.37 & 1.21 & 0.08 \\
\hline CD @ 5\% & 2.05 & 0.51 & 1.22 & 3.93 & 0.26 \\
\hline \multicolumn{6}{|c|}{ Sub plot treatment - Level of nitrogen through FYM } \\
\hline$M_{1}-100 \%$ RDN & 73.44 & 5.31 & 4.09 & 64.26 & 4.97 \\
\hline $\mathrm{M}_{2}-75 \% \mathrm{RDN}$ & 72.92 & 5.08 & 3.27 & 62.26 & 4.76 \\
\hline $\mathrm{M}_{3}-50 \% \mathrm{RDN}$ & 72.33 & 4.89 & 3.17 & 60.97 & 4.71 \\
\hline $\mathrm{M}_{4}-25 \% \mathrm{RDN}$ & 71.80 & 4.84 & 3.00 & 59.70 & 4.55 \\
\hline M5-No FYM (Control) & 70.77 & 4.55 & 2.63 & 58.20 & 4.25 \\
\hline $\mathrm{SE} \pm$ & 0.49 & 0.16 & 0.30 & 1.41 & 0.17 \\
\hline CD@ $9 \%$ & 1.40 & 0.47 & 0.86 & 4.02 & 0.47 \\
\hline \multicolumn{6}{|l|}{ Interaction } \\
\hline $\mathrm{SE} \pm$ & 1.10 & 0.36 & 0.67 & 3.15 & 0.37 \\
\hline CD@ 5\% & NS & $\mathrm{NS}$ & NS & NS & NS \\
\hline General mean & 72.25 & 4.93 & 3.23 & 61.08 & 4.65 \\
\hline
\end{tabular}


Table.2 Yield attributing characters, grain and straw yield and economics ( $\mathrm{qha}^{-1}$ ) of rice as influenced by the different treatments

\begin{tabular}{|c|c|c|c|c|c|c|c|c|c|c|c|}
\hline Treatment & $\begin{array}{c}\text { Length of } \\
\text { panicle } \\
\text { (cm) }\end{array}$ & $\begin{array}{c}\text { Weight of } \\
\text { panicle } \\
\text { (g) }\end{array}$ & $\begin{array}{c}\text { No. of } \\
\text { filled } \\
\text { grains } \\
\text { panicle }^{-1}\end{array}$ & $\begin{array}{c}\text { No. of } \\
\text { unfilled } \\
\text { grains } \\
\text { panicle }^{-1}\end{array}$ & $\begin{array}{c}\text { Test } \\
\text { weight } \\
\text { (g) }\end{array}$ & $\begin{array}{c}\text { Grain } \\
\text { yield } \\
\left(\mathbf{q} \mathbf{h a}^{-1}\right)\end{array}$ & $\begin{array}{c}\text { Straw } \\
\text { yield (q } \\
\left.\text { ha }^{-1}\right)\end{array}$ & $\begin{array}{c}\text { Cost of } \\
\text { cultivation } \\
(\text { Rs. ha-1) }\end{array}$ & $\begin{array}{c}\text { Gross } \\
\text { Returns } \\
\left(\text { Rs. ha }{ }^{-1}\right)\end{array}$ & $\begin{array}{c}\text { Net } \\
\text { Returns } \\
\left(\text { Rs. ha }{ }^{-1}\right)\end{array}$ & $\begin{array}{l}\text { B: C } \\
\text { Ratio }\end{array}$ \\
\hline \multicolumn{12}{|c|}{ Main plot treatment - Level of nitrogen through urea } \\
\hline $\mathrm{N}_{1}-\mathbf{- 1 0 0} \% \mathrm{RDN}$ & 25.55 & 5.95 & 324.54 & 52.41 & 17.39 & 60.86 & 76.73 & 118711 & 125685 & 6974 & 1.06 \\
\hline $\mathrm{N}_{2}-75 \% \mathrm{RDN}$ & 25.22 & 5.70 & 311.09 & 50.00 & 16.95 & 57.57 & 69.70 & 117093 & 118176 & 1083 & 1.01 \\
\hline $\mathrm{N}_{3}-\mathbf{5 0} \% \mathrm{RDN}$ & 25.04 & 5.50 & 305.75 & 45.43 & 16.77 & 54.32 & 63.67 & 115527 & 110977 & -4550 & 0.96 \\
\hline $\mathrm{N}_{4}-25 \% \mathrm{RDN}$ & 24.60 & 5.31 & 293.25 & 39.25 & 16.46 & 51.60 & 58.94 & 114166 & 105043 & -9123 & 0.92 \\
\hline $\begin{array}{l}\mathrm{N}_{5}-\mathrm{No} \text { fertilizer } \\
\text { (Control) }\end{array}$ & 23.88 & 4.84 & 259.82 & 37.32 & 16.17 & 34.68 & 38.72 & 103534 & 70374 & -33160 & 0.68 \\
\hline $\mathrm{SE} \pm$ & 0.13 & 0.14 & 8.28 & 1.64 & 0.15 & 0.85 & 1.01 & & & & \\
\hline CD@ 5\% & 0.42 & 0.47 & 26.99 & 5.35 & 0.48 & 2.77 & 3.30 & & & & \\
\hline \multicolumn{12}{|c|}{ Sub plot treatment - Level of nitrogen through FYM } \\
\hline $\mathrm{M}_{1}-100 \%$ RDN & 25.08 & 5.69 & 308.65 & 47.61 & 17.03 & 54.22 & 65.13 & 150865 & 111162 & -39703 & 0.74 \\
\hline $\mathrm{M}_{3}-50 \% \mathrm{RDN}$ & 24.98 & 5.51 & 303.07 & 45.34 & 16.75 & 52.21 & 61.99 & 113954 & 106864 & -7090 & 0.94 \\
\hline $\mathrm{M}_{4}-25 \% \mathrm{RDN}$ & 24.68 & 5.30 & 290.34 & 44.30 & 16.64 & 50.85 & 60.08 & 95381 & 104006 & 8625 & 1.09 \\
\hline $\mathrm{M}_{5}-\mathrm{No}$ FYM (Control) & 24.51 & 5.19 & 285.47 & 41.00 & 16.49 & 48.48 & 56.83 & 76394 & 99044 & 22650 & 1.30 \\
\hline $\mathrm{SE} \pm$ & 0.13 & 0.13 & 5.64 & 1.44 & 0.07 & 0.39 & 0.44 & 150865 & 111162 & -39703 & 0.74 \\
\hline CD @ 5\% & 0.37 & 0.36 & 16.12 & 4.12 & 0.21 & 1.11 & 1.26 & 132437 & 109180 & -23258 & 0.82 \\
\hline \multicolumn{12}{|l|}{ Interaction } \\
\hline $\mathbf{S E} \pm$ & 0.29 & 0.29 & 12.61 & 3.22 & 0.16 & 0.87 & 0.98 & & & & \\
\hline CD@ 5\% & NS & NS & NS & NS & NS & 2.48 & 2.81 & & & & \\
\hline General mean & 24.86 & 5.46 & 298.89 & 44.88 & 16.75 & 51.81 & 58.95 & & & & \\
\hline
\end{tabular}


Among the various levels the lowest value of thousand grain weight found in control treatment of (16.49 g).It is seen for the data presented in Table 2 that, among the various levels of nitrogen through FYM, the treatment supplied with 100 per cent RDN $\left(\mathrm{M}_{1}\right)$ produced the grain yield at par with $\left(\mathrm{M}_{2}\right) 75$ per cent RDN and it was significantly superior over $\left(\mathrm{M}_{3}\right) 50$ per cent RDN, $\left(\mathrm{M}_{4}\right) 25$ per cent RDN and control $\left(\mathrm{M}_{5}\right)$. Among the different levels of nitrogen application through FYM, the treatment with 100 per cent RDN $\left(M_{1}\right)$ produced significantly higher straw yield $\left(65.13 \mathrm{q} \mathrm{ha}^{-1}\right)$ over rest of the levels i.e. $\left(\mathrm{M}_{2}\right) 75$ per cent $\mathrm{RDN},\left(\mathrm{M}_{3}\right) 50$ per cent RDN, $\left(\mathrm{M}_{4}\right) 25$ per cent RDN and control $\left(\mathrm{M}_{5}\right)$.

Among the levels of nitrogen through FYM, 100 per cent RDN (M1) recorded significantly higher value of growth parameters and yield attributes which resulting into significantly more grain and straw yields (q ha-1) than remaining levels of nitrogen under the investigation. Significantly highest net monitory returns of Rs. 22,650 ha1 and $\mathrm{B}: \mathrm{C}$ ratio of 1.30 registered under the treatment (N5) No FYM (control) than other higher levels of FYM during year of experimentation. Among the different treatment combinations, the highest net returns and $\mathrm{B}: \mathrm{C}$ ratio of Rs. 32, 749 ha- 1 and 1.41, respectively were obtained under treatment combination of (N1M5) i.e. 100 per cent RDN through urea with no FYM.

The remaining treatments can be arranged in the following order of significance i.e. $\left(\mathrm{M}_{2}\right)>$ $\left(\mathrm{M}_{3}\right)>\left(\mathrm{M}_{4}\right)>\left(\mathrm{M}_{5}\right)$. Satyanarayana, et al., (2002) reported that, application of organic materials such as farmyard manure considerably improves soil physical properties and nutrient uptake resulting in greater growth, yield and yield components. Similar finding was confirmed by Singh, et al., (2014).
On the basis of the objectives of the present investigation following conclusions can be made the application of 100 per cent RDN through urea in combination with 100 per cent RDN through FYM recorded significantly higher growth parameters, yield attributes and yield of kharif rice.

\section{References}

Anonymous (2016). Maharashtra State Statistics Dept. of Pune. (2015-16)

Anonymous (2017) Agricultural Statistics at a glance 2017, Directorate of Economics \&Statistics, Ministry of Agriculture \& Farmers Welfare, Govt. of India.

Anonymous (2017) Food and Agriculture Organization of the United Nations (FAO). Rice Market Monitor. April, 2017, 20(1): 1-38.

Babu, A., Verma, S, Yadav, S.S, Singh, Y.V. (2017) Impact of nutrient management technologies, soil biomass and enzymatic activities in transplanted rice (Oryza sativa L.) under irrigated domains of eastern plain zone in India. Int.J.Curr.Microbiol.App.Sci. $\quad$ 6(11): 4219-4227.

Chaturvedi, I. (2005) Effect of nitrogen fertilizers on growth, yield and quality of hybrid rice (Oryza sativa L.) Journal of Central European Agriculture.6(4): 611-618.

Dangi, K (2016) Performance of rice varieties at varying levels of nitrogen under direct seeded upland condition. M. Sc. (Agri.) Thesis Department of Agronomy College of Agriculture, Rewa-486001. Jawaharlal Nehru Krishi Vishwa Vidyalaya, Jabalpur, MP (2016).

Gopakkali, P. (2010) Effect of FYM and cattle urine on growth and yield of irrigated paddy (oryza sativa L.) In bhadra command area. Department of Agronomy University of Agricultural 
Sciences Bengaluru - 560065 .

Kafle, S. (2014) Optimization of nitrogen through organic and inorganic sources for enhancing maize (Zea mays L.) productivity. M. Sc. (Ag.) Thesis, Department of Agronomy College of Agriculture, Punjab Agricultural University, Ludhiana.

Kumar, S., Kour, S., Gupta, M., Kachroo, D. and Singh, H. (2017) Influence of rice varieties and fertility levels on performance of rice and soil nutrient status under aerobic conditions. Journal of Applied and Natural Science. 9(2):1164-1169.

Marskole, V. P. (2017) Effect of nutrient management on productivity and economics of Rice. M.Sc. (Agri.) Thesis (Unpub.), JNKVV, Jabalpur.

Satyanarayana,V., Prasad, V., Murthy, V.R. and Boote, K. J. (2002) Influence of integrated use of farm yard manure and inorganic fertilizers on yield and yield components of irrigated lowland rice. Journal of Plant Nutrition (25): 2081-2090.
Shah, S.H., Saleem, M.F., Shahid, M. (2001) Effect of different fertilizers and effective microorganisms on growth, yield and quality of maize. International Journal of Agriculture \& Biology. 3(4): 378-379.

Singh, S., Singh, S. P., Neupane, M. P. and Meena, R. K. (2014) Effect of NPK levels, BGA and FYM on growth and yield of rice (Oryza sativa L.) Environment \& Ecology. 32 (1A):301303.

Srivastava, V.K., Bohra, J.S. and Singh, J.K. (2013) Effect of integration of NPKlevels and organic sources on growth, yield and economics of rice. Adv. Res. J. Crop Improv. 4(2):113117.

Yadav, O.M., Dahiphale, V.V. And Godhawale, G.V. (2008) Effect of integrated nutrient management on production and economic efficiency of Rice (Oryza sativa L.) under upland drilled condition. Indian J. Dryland Agric. Res. \& Dev. 23(1):13-18.

\section{How to cite this article:}

Warankar, V. V., Y. S. Chavan, A. N. Jadhav, M. E. Bahiram, A. M. Gaikwad, V. G. Chavan, VA. Rajemahadik, VV. Sagavekar and Chavan, S. A. 2020. Nutrient Management in kharif Rice (Oryza sativa L.) through Inorganic and Organic Sources for Enhancing Productivity and Profitability in konkan Region of Maharashtra. Int.J.Curr.Microbiol.App.Sci. 9(12): 355-364. doi: https://doi.org/10.20546/ijcmas.2020.912.045 